\title{
RANGE EXTENSION OF THE NORTHERN NAKED-TAILED ARMADILLO (CABASSOUS CENTRALIS) IN SOUTHERN MEXICO
}

\author{
Rugieri Juárez-López ${ }^{1}$, Mariana Pérez-López ${ }^{1}$, Yaribeth Bravata-de la Cruz ${ }^{1}$, Alejandro Jesús-de la Cruz ${ }^{1}$, \\ Fernando M. Contreras-Moreno ${ }^{1}$, Daniel Thornton ${ }^{2,3}$, and Mircea G. Hidalgo-Mihart ${ }^{1,4}$
}

\begin{abstract}
The northern naked-tailed armadillo (Cabassous centralis) is one of the least known armadillo species. Due to its restricted distribution in Mexico and the few known records of the species, the northern naked-tailed armadillo is considered endangered by Mexican law. Using camera traps, we obtained a new record in Portaceli, Chiapas, an area where the species was not previously recorded. The record was located $75 \mathrm{~km}$ north of the previously known range of the species in Mexico, and thus constitutes a range expansion of the species in the country. This record suggests that the species could be present in areas with similar environmental conditions where mammal research has been limited, especially in Tabasco, Mexico, and in Sierra del Lacandón, Guatemala. It is necessary to generate additional information on the species in order to determine the current status of the northern naked-tailed armadillo in Mexico.
\end{abstract}

REsumen.-El armadillo de cola desnuda (Cabassous centralis; ACD) es una especie de hábitos poco conocidos, considerada en peligro de extinción por las leyes mexicanas. El armadillo cola desnuda presenta una distribución restringida en México y se cuenta con pocos registros en el país. Utilizando cámaras trampa obtuvimos una fotografía de ACD en Portaceli, Chiapas, un área nueva para la especie al noreste de Chiapas. El registro del armadillo se localizó $75 \mathrm{~km}$ al norte del área de distribución conocida de la especie en México, lo que constituye una ampliación en el área de distribución de la especie. El registro implica que probablemente la especie se encuentra presente en áreas poco estudiadas desde el punto de vista mastozoológico y ambientalmente similares localizadas en Guatemala y México, especialmente en la región del Cañón del Usumacinta. Se debe incrementar la información del armadillo cola desnuda en México con el fin de determinar el estatus que presenta en el país.

The northern naked-tailed armadillo (Cabassous centralis) is a small armadillo, with adults weighing from 2 to $3.5 \mathrm{~kg}$ (Hayssen et al. 2013). The distribution of the northern nakedtailed armadillo ranges from southeastern Chiapas in Mexico to northern Colombia and across Venezuela as far as the state of Monagas and the coastal lowlands of northwestern Ecuador (Hayssen et al. 2013). This species is one of the least known armadillo species (Superina et al. 2014) and is considered by the IUCN as data deficient (Tirira et al. 2014).

The northern naked-tailed armadillo was recorded for the first time in Mexico in 1986 (Cuarón et al. 1989) and since that date has been recorded on several occasions along the Selva Lacandona area in southeastern Chiapas (see González-Zamora et al. 2011 for a review). With the exception of some observations about denning habits, activity patterns (Figueroa-deLeón et al. 2016), and habitat use (GonzálezZamora et al. 2011), information about the biology of the northern naked-tailed armadillo in its northern range is almost nonexistent. The species is considered endangered in Mexico (NOM-059-SEMARNAT-2010; Official Journal of the Federation 2010), and its identified main mortality sources are subsistence hunting and roadkills (González-Zamora et al. 2011). However, the response of the species to habitat loss is not clear because there is not enough available information (Tirira et al. 2014). However, limited work suggests that the northern naked-tailed armadillo is associated with both primary and secondary tropical forests (Cuarón 2000) and is commonly recorded inside isolated patches of tropical forests (González-Zamora et al. 2011, Garmendia et al. 2013).

As part of a study aimed at identifying areas that are important for the conservation of the jaguar (Panthera onca) and its prey in northern Chiapas and eastern Tabasco, we set up camera traps throughout the municipalities of Emiliano Zapata and Tenosique in Tabasco, and La Libertad and Palenque in Chiapas,

\footnotetext{
IDivisión Académica de Ciencias Biológicas, Universidad Juárez Autónoma de Tabasco, C.P. 86040, Villahermosa, Tabasco, México.

${ }^{2}$ School of Environment, Washington State University, 100 Dairy Road/1228 Webster, Pullman, WA 99164-2812.

${ }^{3}$ Panthera, 8 West 40th Street, 18th Floor, NY 10018.

${ }^{4}$ Corresponding author. Email: mhidalgo@yahoo.com
} 
during 2016-2017. With these cameras, we obtained the first record of the northern naked-tailed armadillo in northeastern Chiapas. This record expanded the species' range by $75 \mathrm{~km}$ from the previously known northernmost record of the species (Cuarón et al. 1989).

The study area was located $25 \mathrm{~km}$ west of the city of Tenosique, Tabasco, and lies within the ejido (Mexican communal land under the stewardship of rural inhabitants and used for agriculture) of Portaceli, municipality of Palenque, Chiapas (Fig. 1). The area was located in the northern portion of the Selva Lacandona Region in Chiapas, a region of valleys and low hills that varies from 100 to $500 \mathrm{~m}$ asl. Climate in the region was warm (mean annual temperature, $26^{\circ} \mathrm{C}$ to $28^{\circ} \mathrm{C}$ ) with substantial precipitation (3000-3500 mm annually; Instituto Nacional de Estadística y Geografía 2015). The original vegetation of the area was tropical rainforest (Rzedowski 2006), but the region has been heavily impacted by agriculture and cattle ranching over the last 20 years (Kolb and Galicia 2012), producing a landscape dominated by cattle pasture and crops in the valleys and a mixture of primary and secondary forest in the surrounding hills. The region is included in Priority Land Region 138 Lacandona (Región Terrestre Prioritaria; Arriaga et al. 2000) and is adjacent to the federal natural protected area Cañón del Usumacinta Flora and Fauna Protection Area.

We set 82 camera trap stations (Pantheracam Model IV and V; Olliff et al. 2014) from October 2016 to January 2017 in northeastern Chiapas and eastern Tabasco. We set the traps along pathways, firebreaks, and roads in the region. We tied the cameras to trees at a height of $50 \mathrm{~cm}$ and programmed them to function $24 \mathrm{~h}$ per day. To increase the visitation rate of carnivores at the camera sites, we baited the sites with canned sardines. Cameras were separated by at least $1 \mathrm{~km}$.

The northern naked-tailed armadillo picture was obtained on 10 December 2016 at 04:09 at a camera trap located on a dirt road inside an area of secondary growth forest (UTM zone 15N 649574, 1915570; Fig. 2). The image shows a partial view of a single individual of unknown sex. In the study area, the only previously reported armadillo species is the nine-banded armadillo (Dasypus novemcinctus). Compared to the northern naked-tailed armadillo, the nine-banded armadillo is larger and has a long and armored tail, small scutes along the body, and a series of only 8-9 conspicuous movable bands on the back (Reid 2009). The armadillo in the camera trap picture has a small and unarmored tail, scutes larger than reported for the nine-banded armadillo, and at least 12 barely visible bands on its back, characteristics that correspond to the northern naked-tailed armadillo (Reid 2009).

In order to document records of the presence of the northern naked-tailed armadillo in the study area, we searched for records in published reports of the mammal fauna in the area (Reyes-Castillo 1978, Soto-Shoender 2003, Guzmán-Aguirre and Bello-Gutiérrez 2006, Vaca-León 2014, Gordillo-Chávez et al. 2015) and for occurrence data in web-based databases, including the Global Biodiversity Information Facility (GBIF; www.gbif.org), Mammal Networked Information System (MaNIS; manisnet.org), and Naturalista (www .naturlista.org). We did not find any records of the northern naked-tailed armadillo in previously published reports of mammal fauna in the area. However, we found 5 GBIF records of the species georeferenced in the database outside the known range in Mexico (GBIF records 1418821255, 1418809374, and 1418804329 from "Lacanja-Chansayab" and records 1418804311 and 1418809397 from "Crucero a Frontera Corozal"). These out-ofrange northern naked-tailed armadillo records were part of a project to georeference the records of Mexican mammals (Ceballos 2002), and the voucher specimens were located at the Colección Nacional de Mamíferos of the Universidad Nacional Autónoma de Mexico (CNMA). The search for northern nakedtailed armadillo records in the CNMA database subsetted from the full GBIF database only returned information of records inside the known naked-tailed armadillo range in Mexico, indicating that the out-of-range records are not referenced in the CNMA. Also, the reference localities of the GBIF out-ofrange records ("Lacanja-Chansayab and "Crucero a Forntera Corozal") are located inside the known range of the species (Fig. 1), indicating that the georeferencing of these particular records is not accurate.

The northern naked-tailed armadillo record in Portaceli, Chiapas, increases the range of the species in Mexico by $75 \mathrm{~km}$ from the closest 


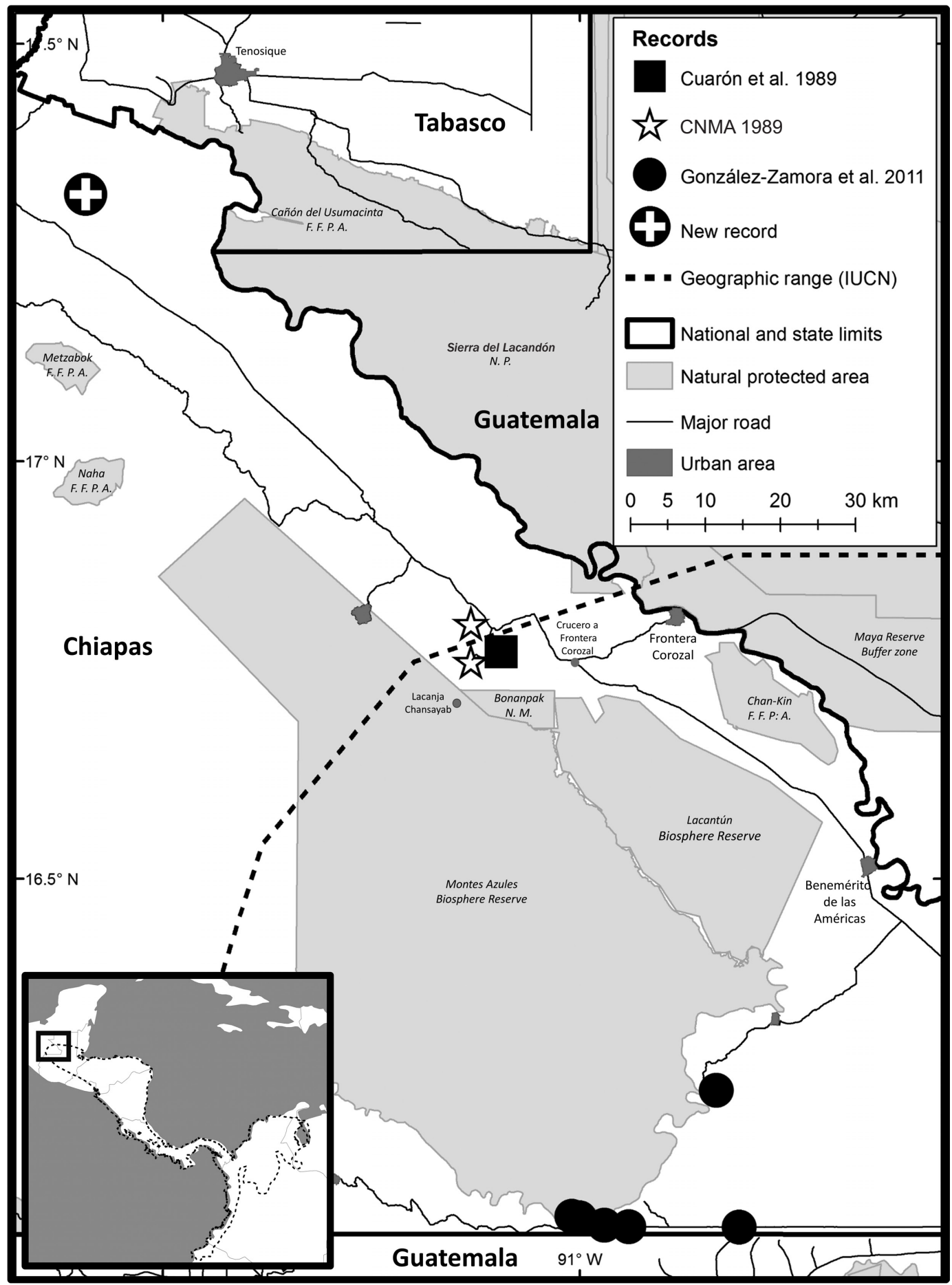

Fig. 1. Map of the study area location in northeastern Chiapas, Mexico, indicating the site where the northern nakedtailed armadillo was recorded relative to the current geographic range of the species (Tirira 2014) and previous records of the species in Mexico (Cuarón 1989, González-Zamora et al. 2011) 


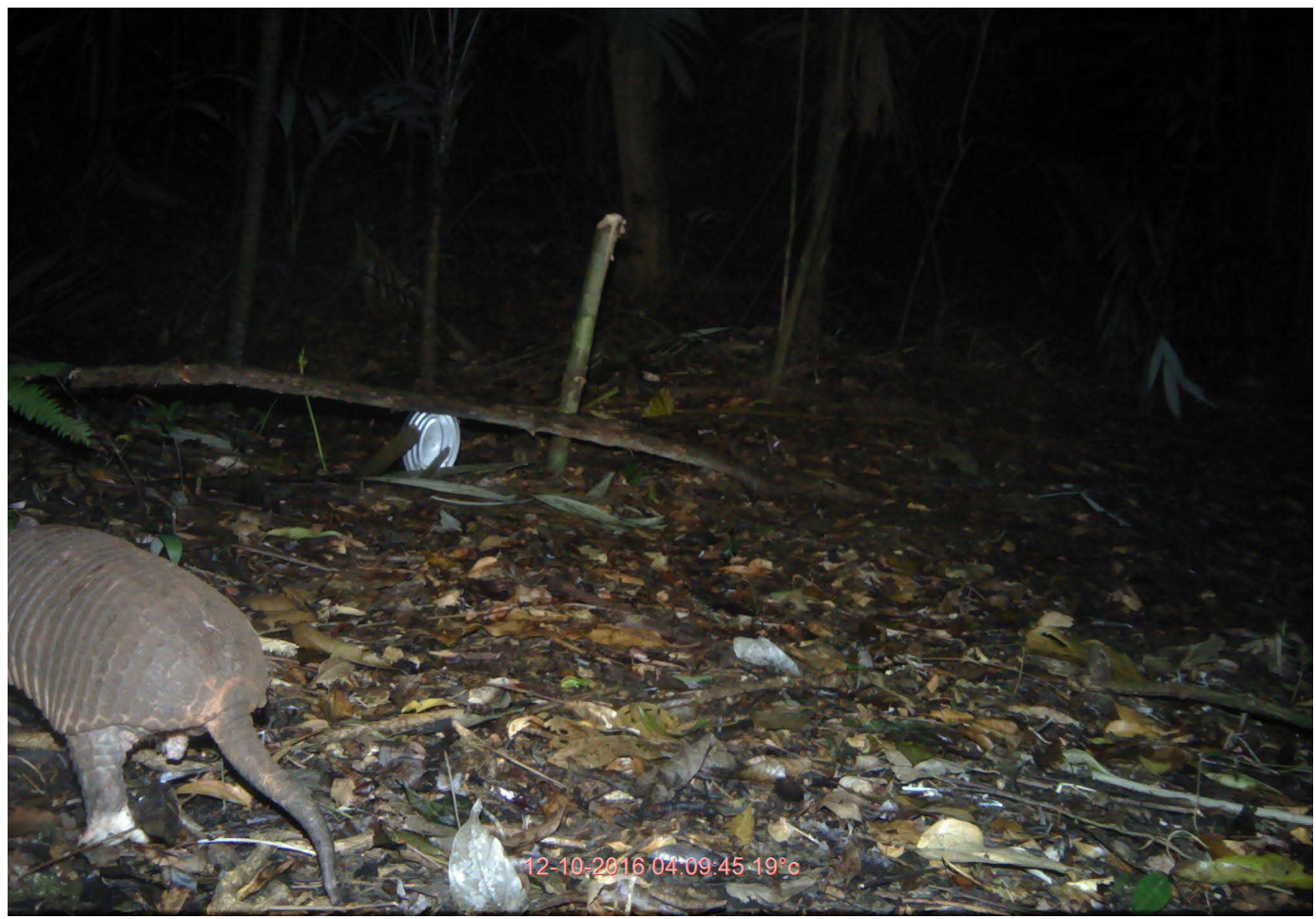

Fig. 2. Photograph of a northern naked-tailed armadillo obtained on 10 December 2016 (time: 04:09) in Ejido Portaceli, northeastern Chiapas, Mexico.

confirmed record located in the Bonampak and Frontera Corozal, and $110 \mathrm{~km}$ from the Loma Bonita record near the border of Guatemala (Fig. 1). Diversity and distribution of the mammal fauna of Chiapas State is one of the best known in southeastern Mexico (Naranjo et al. 2016). However, the region where this new record was obtained in northeastern Chiapas has seen limited mammal research (Escalante et al. 2002). Thus, new mammal surveys in the area may find new naked-tailed armadillo records in areas such as the Sierra del Lacandón National Park in Guatemala and portions of Tabasco State where the species has not been previously recorded (Hidalgo-Mihart et al. 2016), particularly the Cañon del Usumacinta Flora and Fauna Protection Area.

We only obtained one photograph of the northern naked-tailed armadillo in 7380 camera days (one camera day is equivalent to one camera trap station working continuously for $24 \mathrm{~h})$. In comparison, we obtained 81 photographs of the nine-banded armadillo in the same period. Thus, apparently, the abundance of the northern naked-tailed armadillo in the area is very low. However, because the study was intended to photograph jaguars and their main medium- and large-sized mammal prey species (e.g., white-tailed deer Odocoileus virginianus, collared peccary Pecari tajacu, etc.), the cameras were located in pathways, firebreaks, and roads, and not directed to detect the presence of species with semifossorial habits such as the naked-tailed armadillo (i.e., camera traps were not located outside holes in the ground with the potential use by mammals as dens or resting sites; Figueroa-de-León et al. 2016), reducing our capabilities to obtain photographic records of the species.

Our findings, which substantially expand the northward range edge of a poorly known large mammal, suggest that it will be important to conduct more studies to detect the presence of the species in northeastern Chiapas and southeastern Tabasco, along with the Sierra del Lacandón area of Guatemala. Research of this kind will be particularly 
important given the rapid deforestation currently occurring in the region. A better understanding of habitat associations and mortality sources (González-Zamora et al. 2011) will be needed to determine the likely population trajectory of the species in this region as the human population size increases and landscape transformation continues to accelerate (Kolb and Galicia 2012).

This study was performed with support from Panthera through the project "Evaluation of Three Corridors in Southeastern Mexico for Jaguars" We are grateful to the authorities and inhabitants of the Ejido Portaceli for allowing us to carry out this study on their land. We thank the División Académica de Ciencias Biológicas of the Universidad Juárez Autónoma de Tabasco (DACBiol-UJAT) for logistical support. RJL received a scholarship from Consejo Nacional de Ciencia y Tecnologia for his MSc degree in Environmental Sciences at DACBiol-UJAT and was supported by the project FOMIX, Gobierno del Estado de Tabasco (CONACYT - FOMIX 2014-03245836), "Fortalecimiento de la Maestría en Ciencias Ambientales para su permanencia en el Padrón Nacional de Posgrados de Calidad del Conacyt.”

\section{Literature Cited}

Arriaga, L., J.M. Espinoza, C. Aguilar, E. Martínez, L. Gómez, and E. Loa Coordinadores. 2000. Regiones terrestres prioritarias de México. Comisión Nacional para el Conocimiento y uso de la Biodiversidad, México. http://www.conabio.gob.mx/conocimi ento/regionalizacion/doctos/Tacerca.html

Ceballos, G. 2002. Actualización de la base de datos del Atlas Mastozoológico de México. Universidad Nacional Autónoma de México. Instituto de Ecología. Bases de datos SNIB-CONABIO proyectos No. T009 y A003. México, D.F.

Cuarón, A.D. 2000. Effects of land cover changes on mammals in a neotropical region: a modeling approach. Conservation Biology 14:1676-1692.

Cuarón, A.D., I.J. March, and P.M. Rockstroh. 1989. A second armadillo (Cabassous centralis) for the faunas of Guatemala and Mexico. Journal of Mammalogy 70:870-871.

Escalante, T., D. Espinosa, and J.J. Morrone. 2002. Patrones de distribución geográfica de los mamíferos terrestres de México. Acta Zoológica Mexicana (n.s.) $87: 47-65$.

Figueroa-De-León, A., E.J. Naranjo, and A. SantosMoreno. 2016. Registros de Cabassous centralis (Cingulata: Dasypodidae) en la Reserva de la Biosfera Montes Azules y sitios aledaños, Chiapas, México. Edentata 17:46-50.
Garmendia, A., V. Arroyo-Rodríguez, A. Estrada, E.J. NARAnjo, AND K.E. Stoner. 2013. Landscape and patch attributes impacting medium- and large-sized terrestrial mammals in a fragmented rain forest. Journal of Tropical Ecology 29:331-344.

González-Zamora, A., V. Arroyo-Rodríguez, A.M. González-Di Pierro, R. Lombera, De E. La PeñaCuéllar, J.L. Peña-Mondragón, O. HernándezOrdoñez, C. Muench, A. Garmendia, and K.E. STONER. 2011. The northern naked-tailed armadillo in the Lacandona rainforest, Mexico: new records and potential threats. Revista Mexicana de Biodiversidad 82:581-586.

Gordillo-Chávez, E.J., E.E. Mata, R. García-Morales, M.A. Morales, C. Villanueva, and J.D. ValdezLEAL. 2015. Mastofauna del humedal Chaschoc-Sejá en Tabasco, México. Therya 6:535-544.

GuZmán-Aguirre, C.C., ANd J. Bello-GutiérRez. 2006. Mamíferos de Boca del Cerro Tenosique, Tabasco, México. Kuxulkab Revista de Divulgación 11:75-81.

Hayssen, V., J. Ortega, A. Morales-Leyva, and N. Martínez-MÉndez. 2013. Cabassous centralis (Cingulata: Dasypodidae). Mammalian Species 45:12-17.

Hidalgo-Mihart, M.G., F.M. Contreras-Moreno, A. Jesús-De la Cruz, D. Jiménez-Domínguez, R. Jú́rez-López, S. OPORTO-PEREgrino, AND Y.R. ÁvilAFlores. 2016. Mamíferos del estado de Tabasco. Pages 441-472 in M. Briones-Salas, Y. HortelanoMoncada, G. Magaña-Cota, G. Sánchez-Rojas, and J.E. Sosa-Escalante, editors, Riqueza y conservación de los mamíferos en México a nivel estatal. Instituto de Biología-UNAM, Asociación Mexicana de Mastozoología and Universidad de Guanajuato, Ciudad de México, México.

Instituto Nacional de Estadística y Geografía. 2015. Anuario estadístico y geográfico de Chiapas. Instituto Nacional de Estadística y Geografía y Gobierno del Estado de Chiapas, Aguascalientes, México.

Kolb, M., AND L. GaLiCia. 2012. Challenging the linear forestation narrative in the Neo-tropic: regional patterns and processes of deforestation and regeneration in southern Mexico. Geographical Journal 178: $147-161$.

Naranjo, E.J., C. Lorenzo, J. Bolaños-Citalán, and A. Honváth. 2016. Mamíferos de Chiapas, México. Pages 155-177 in M. Briones-Salas, Y. HortelanoMoncada, G. Magaña-Cota, G. Sánchez-Rojas, and J.E. Sosa-Escalante, editors, Riqueza y conservación de mamíferos en México a nivel estatal. Instituto de Biología-UNAM, AMMAC and Universidad de Guanajuato, Ciudad de México, México.

OfFicial Journal of the Federation. 2010. NOM-059SEMARNAT-2010. 2010. Protección AmbientalEspecies Nativas de México de Flora y Fauna Silvestres-Categorías de Riesgo y Especificaciones Para su Inclusión, Exclusión o Cambio-Lista de Especies en Riesgo. Diario Oficial de la Federación. 30 de Diciembre de 2010. Distrito Federal, México. $78 \mathrm{pp}$.

Olliff, E.R.R., C.W. Cline, D.C. Bruena, E.J. YarmChuk, R.S.A. Pickles, and L. Hunter. 2014. The Panthercam-a camera-trap optimized for monitoring wild felids. Wild Felid Monitor 7:21-28.

REID, F. 2009. A field guide to the mammals of Central America and southeast Mexico. 2nd edition. Oxford University Press. 384 pp. 
Reyes-Castillo, P. 1978. La fauna silvestre en el Plan Balancán Tenosique. INIREB Biblioteca del Instituto de Ecología, Xalapa, México.

Rzedowski, J. 2006. Vegetación de México. Comisión Nacional para el Conocimiento y Uso de la Biodiversidad, Distrito Federal, México.

Soto-Shoender, J.R. 2003. Impactos de cacería de una comunidad del Parque Nacional Sierra del Lacandón, La Libertad, Petén sobre vertebrados mayores terrestres y arbóreos. Facultad de Ciencias Químicas y Farmacia, Escuela de Biología. Universidad de San Carlos, Guatemala, Guatemala.

Superina, M., N. PagnutTi, And A.M. AbBa. 2014. What do we know about armadillos? An analysis of four centuries of knowledge about a group of South American mammals, with emphasis on their conservation. Mammal Review 44:69-80.
Tirira, D.G., J. Díaz-N., M. Superina, and A.M. Abba. 2014. Cabassous centralis. The IUCN Red List of Threatened Species 2014: e.T3412A47437304. [Accessed 6 February 2017]. http://dx.doi.org/10 .2305/IUCN.UK.2014-1.RLTS.T3412A47437304.en

VACA-LEÓN, L.M.C. 2014. De lo social a lo ecológico: explorando el conflicto humano jaguar (Panthera onca) y la viabilidad de su conservación en dos comunidades de la Selva Lacandona, Chiapas. Bachelors Social Service Report, Universidad Autónoma Metropolitana-Xochimilco, Ciudad de México, México.

Received 28 February 2017 Accepted 31 July 2017 Published online 29 September 2017 